\title{
Property, Plant and Equipment disclosure requirements and firm characteristics: the Portuguese Accounting Standardization System
}

\author{
Rafaela BOTELHO ${ }^{1}$ \\ Graça AZEVEDO \\ Alberto COSTA ${ }^{3}$ \\ Jonas OLIVEIRA ${ }^{4}$ \\ 1,2,3,4 Higher Institute for Accountancy and Administration, University of Aveiro, Portugal, \\ ${ }^{1}$ E-mail: rafaelabotelho@ua.pt, ${ }^{2} E$-mail: graca.azevedo@ua.pt, \\ ${ }^{3} E$-mail: alberto.costa@ua.pt, ${ }^{4} E$-mail: jonas.oliveira@ua.pt
}

\begin{abstract}
In the new Portuguese accounting frame of reference (Portuguese Accounting Standardization System Sistema de Normalização Contabilística), the issues related to Property, Plant and Equipment assets are dealt with in the Accounting and Financial Reporting Standard (Norma Contabilística de Relato Financeiro - NCRF) 7 (Property, Plant \& Equipment). The present study intends to assess the degree of compliance with the disclosure requirements of this accounting standard by Portuguese unlisted companies. Moreover, it tries to identify the factors that influence their level of disclosure. The financial statements for 2010 and 2011 were content analyzed and a multiple linear regression model was used to assess the motivations for companies to comply with disclosure requirements. Results indicate that older companies with lower levels of foreign activity present higher levels of disclosures. The type of auditing firm is also a factor that influences the level of compliance with NCRF 7.
\end{abstract}

Key words Reporting, Disclosure, Mandatory, Property, Plant, Equipment

DOI: 10.6007/IJARAFMS/v5-i1/1459

URL: http://dx.doi.org/10.6007/IJARAFMS/v5-i1/1459

\section{Introduction}

Regulation (EC) No 1606/2002 of the European Parliament and Council granted European member states the freedom to choose which accounting frame of reference to be applied by companies with no securities listed in regulated stock exchange markets: International Accounting Standards/International Financial Reporting Standards (IAS/IFRS), or other domestic accounting frames of reference.

In July 2009, Portugal approved the Accounting Standardization System (Sistema de Normalização Contabilística - SNC) superseding the previous accounting frame of reference: Portuguese Accounting Plan (Plano Oficial de Contabilidade - POC).

In the SNC, issues related to property, plant and equipment are dealt with in the Accounting and Financial Reporting Standard (Norma Contabilística de Relato Financeiro-NCRF) 7 (Property, Plant \& Equipment). Property, Plant \& Equipment (PPE) "increasingly present themselves as a key factor in the financial statements of companies due to its capital intensive" (Cunha and Ribeiro, 2008, p. 1).The present study focuses on the PPE, basically because the accounting treatments proposed by the SNC are very different from those required by the previous POC. The analysis of NCRF7 regarding compliance with its disclosure requirements would provide users of financial information with the most comprehensive knowledge about them, minimizing errors in their applicability. Therefore, the present study aims to analyze the degree of compliance with the disclosures required by NCRF 7, and the factors that influence the level of disclosure on PPE.

Trombetta et al. (2012) highlight the importance of studies of this nature, both for the users of financial information and for the proper standardization bodies, as they help to understand the effects of 
accounting standards. These authors also report that academic studies should be a primary resource for the standardization bodies so that they can understand and improve the impact of accounting standards.

Main findings indicate very interesting levels of compliance with the disclosure requirements of NCRF 7. The age of the company, the degree of internationalization and the kind of auditing firm are the main factors explaining these levels of compliance.

In the following section, we will contextualize the regulatory setting in Portugal, present the literature review, and develop the hypotheses. Thereafter, we will explain our research method, report results, and present our conclusions.

\section{SNC versus POC: disclosure requirements}

The SNC is based on IAS/IFRS. However, in the previous accounting frame of reference there was the possibility to adopt the IAS/IFRS on a supplementary basis. Nevertheless, in terms of Property, Plant and Equipment, the SNC's disclosure requirements are more exhaustive than those required in the POC. The main differences between the POC and the SNC are shown in Table 1.

Table 1. Property, Plant \& Equipment disclosure requirements

\begin{tabular}{|c|c|}
\hline SNC & POC \\
\hline $\begin{array}{l}\text { For each class of property, plant \& equipment: } \\
\text { - Measurement bases, depreciation methods, } \\
\text { useful lives/depreciation rates, gross carrying } \\
\text { amount and the accumulated depreciation } \\
\text { (aggregated with accumulated impairment } \\
\text { losses) at the beginning and end of the period, } \\
\text { reconciliation of the gross carrying amount at } \\
\text { the beginning and end of the period; } \\
\text { Restrictions on title and items pledged as } \\
\text { security for liabilities; } \\
\text { Expenditures to construct property, plant, and } \\
\text { equipment during the period; } \\
\text { Contractual commitments to acquire property, } \\
\text { plant, and equipment; } \\
\text { Compensation from third parties for items of } \\
\text { property, plant, and equipment that were } \\
\text { impaired, lost or given up that is included in } \\
\text { profit or loss; } \\
\text { If property, plant, and equipment is stated at } \\
\text { revalued amounts: } \\
\text { - the effective date of the revaluation; } \\
\text { - whether an independent evaluator was } \\
\text { involved; } \\
\text { - for each revalued class of property, the } \\
\text { carrying amount that would have been } \\
\text { recognised had the assets been carried under } \\
\text { the cost model; } \\
\text { - the revaluation surplus, including changes } \\
\text { during the period and any restrictions on the }\end{array}$ & $\begin{array}{l}\text { For each class of property, plant \& equipment: } \\
\text { - measurement bases, depreciation methods, } \\
\text { reconciliation of the gross carrying amount at } \\
\text { the beginning and end of the period; } \\
\text { If property, plant and equipment is stated at } \\
\text { revalued amounts: } \\
\text { - indication of the legal pronouncements that } \\
\text { have allowed the revaluation of these assets; } \\
\text { - indication of the methods to deal with } \\
\text { inflation, in the case of using other techniques } \\
\text { to revalue the assets; } \\
\text { - Reconciliation of all items revalued } \\
\text { considering their gross carrying amounts } \\
\text { measured at cost and revalued amounts. } \\
\text { For each class of property, plant \& equipment: } \\
\text { - the amount of items in the possession of } \\
\text { third parties; } \\
\text { - the amount of items allocated to each } \\
\text { company's activities; } \\
\text { - the amount of items located abroad; } \\
\text { - the amount of items that are reversal }\end{array}$ \\
\hline
\end{tabular}


distribution of the balance to shareholders.

\section{Literature Review}

There is a vast literature on the economic effects of the transition and implementation process of IAS/IFRS in terms of the: a) quantitative impacts of IAS/IFRS adoption (Callao et al., 2007; Lantto \& Sahlström, 2009; Haller et al., 2009; Callao et al., 2010; Beuren et al., 2008; latridis \& Rouvolis, 2010); b) IAS/IFRS adoption and its value relevance (Daske et al., 2008; Morais \& Curto, 2008; Aharony et al., 2010; Armstrong et al., 2010; Devalle et al., 2010); conservatism (Tsalavoutas \& Evans, 2007; Fifield et al., 2011; Liu, 2011); IAS/IFRS adoption and earnings management (Tendeloo \& Vanstraelen, 2005; Gassen \& Sellhorn, 2006; Goncharov \& Zimmermann, 2006; Ding et al., 2007; Barth et al., 2008; Jeanjean and Stolowy, 2008).

In terms of the quantitative effects of IAS/IFRS adoption, prior literature has shown that differences are due to fair value issues and the recognition of construction contracts, tangible/intangible assets, provisions and contingent liabilities/assets, and business combinations (Haller et al., 2009; Lantto \& Sahlström, 2009). The present study intends to assess the potential impacts of the first adoption of SNC (which is based on IAS/IFRS) on the accounting treatment of PPE assets, and to analyze the determinants that explain the levels of compliance with mandatory disclosures required by this new accounting frame of reference.

The reasons behind a certain disclosure behavior are complex and a number of theories have been developed to explain it, such as, the agency theory (Jensen \& Meckling, 1976), the signalling theory (Ross, 1977; Morris, 1987), the neo-institutional theory (Olivier, 1991; Fernández-Alles \& Valle-Cabrera, 2006), the legitimacy theory (Shocker \& Sethi, 1974), the stakeholder theory (Freeman, 1984), and the political costs theory (Watts \& Zimmerman, 1986; Birt et al., 2006).

The agency theory explains how the information asymmetry between shareholders and managers can be reduced by the implementation of incentives for managers and mechanisms to monitor their attitudes towards risk and to assure the disclosure of information beyond the strictly necessary (Jensen and Meckling, 1976).

The signalling theory explains managers' attitudes to voluntarily disclose more information to the market than the one required by regulations, so as to signal their behaviour of best practice as a tactic to promote transparency, with the intention of attracting more investment (Ross, 1977; Morris, 1987; Christensen, 2002). Consequently, the companies operating in the same industry will be interested in disclosing at least the same level of information, because they do not want to be under valuated by the market, displaying mimetic isomorphism (DiMaggio and Powell, 1983).

Neo-institutional and legitimacy theories try to explain that this mimetic isomorphism behaviour is a way of reducing the transaction costs associated with the information asymmetry, in order to generate conformity with institutional and societal pressures and gain legitimacy in society by showing that the entity's actions are desirable, proper, or appropriate within some socially constructed system of norms, values, beliefs, and definitions (Olivier, 1991; Fernández-Alles and Valle-Cabrera, 2006; Deephouse, 1996).

The stakeholder theory explains the influence of stakeholders on firms' decisions and, consequently, the role of management to achieve the exact level of stakeholder demand. If the level of stakeholder power increases, so does the importance of meeting stakeholders demand (Freeman, 1984).

The political costs theory explains that, to mitigate potential political costs which are politically visible, companies increase their disclosures, in order to manipulate their image and divert the attention of others (Birt et al., 2006; Watts and Zimmerman, 1986).

Based on information from previous studies on the motivations for corporate disclosures among Portuguese companies, we propose the following explanatory variables: company size, leverage, foreign activity, profitability, and age (Lopes and Rodrigues, 2007; Oliveira et al., 2006; Oliveira et al., 2011a, 2011b).

\section{Development of hypotheses}

\section{Company size}


The agency theory predicts that a larger company is more prone to conflicts between managers and investors, implying the existence of agency costs. Thus, managers have more incentives to disclose more information so as to reduce agency costs. On the other hand, larger companies are more publicly visible to relevant stakeholders, and, therefore, managers are more prone to satisfy the best interests of stakeholders by disclosing information, through a legitimation process to manage corporate reputation (Oliveira et al., 2011a; Watts and Zimmerman, 1986).

Hackston and Milne (1996) and Oliveira et al. (2006) studied and concluded that this variable is positively associated with the amount of disclosure, and, for that reason, larger companies disclose more information. Lopes and Rodrigues (2007) found a statistically significant positive association between this variable and the level of disclosure. Moreover, Akhtaruddin (2005) and Aljifri (2008) concluded that the company size has little impact on the dissemination of information. Finally, Morais and Fialho (2008) and Gastón et al. (2010) found no association between firm size and the degree of disclosure.

Given the diversity of results obtained in the studies mentioned above, the following hypothesis has been formulated:

H1) The number of disclosures on PPE are positively associated with company size.

\section{Leverage}

According to the agency theory, companies highly leveraged have more incentives to disclose information in order to reduce their agency costs (Jensen and Meckling, 1976). On the other hand, the signalling theory indicates that companies with lower levels of leverage have more incentives to signal the market with information about their financial structure.

Previous studies showed that there is no clear relationship between "leverage" and the level of disclosure. Archambault and Archambault (2003) and Oliveira et al. (2006) concluded that it does not influence the level of disclosure. Adelopo (2011) concluded that this variable has a statistically significant negative correlation. latridis (2012) concluded that this variable has a positive change, but not statistically significant in relation to the degree of disclosure.

Because of contradictory evidence from previous studies, it is expected that the sign of this variable is negative. This assumption has led us to the formulation of the following hypothesis:

H2) The number of disclosures on PPE are associated with the company's leverage level.

\section{Foreign Activity}

Few studies included "foreign activity" as a determining factor in the level of disclosure. According to Cooke (1989), Raffournier (1995), and Depoers (2000), companies with an international presence have more incentives to manage stakeholders' perception of their good corporate reputation management skills, through the disclosure of more information. Oliveira et al. (2006) studied this variable stating that company internationalization increased the levels of disclosure; however, no relationship between the variable "foreign activity" and the level of disclosure was found in that same study. Gastón et al. (2010) estimated the "foreign activity" through foreign sales and concluded that the effect of IAS/IFRS was less significant in companies with a higher proportion of foreign sales over total sales.

According to the previous studies, it is expected that there is no significant association between the FTA level of disclosure and "foreign activity". Thus, the following hypothesis has been formulated:

H3) The number of disclosures on PPE are positively associated with the foreign activity of the company.

\section{Profitability}

The political costs theory suggests that profitable companies have higher incentives to disclose more information, because company profits influence a company's political visibility (Hibbitt, 2004). However, previous studies have shown that the "profitability" does not influence the level of disclosure (Aljifri, 2008; Hackston and Milne, 1996; Morais and Fialho, 2008; Oliveira et al., 2006). In addition, Akhtaruddin (2005) noted that there is very little relationship between "profitability" and the level of disclosure. Nevertheless, 
some authors have confirmed the existence of a positive association between performance and the level of disclosure (Lang and Lundholm, 1992; Salotti and Yamamoto, 2008; Cunha and Ribeiro, 2008).

Based on previous studies, the following hypothesis has been formulated:

H4) The number of disclosures on PPE are positively associated with the company's profitability.

Age

Reputation arises from "learning over time through observed behaviour about some exogenous characteristic of agents" (Diamond, 1989, p. 829). Therefore, in order to manage their reputation, older companies are expected to present higher levels of compliance with disclosure requirements. Akhtaruddin (2005) classified the companies into three categories: very old, old, and new. This author did not support the hypothesis that older firms provide more information than new firms.

For this reason, the following research hypothesis has been formulated:

H5) The number of disclosures on PPE are positively associated with the age of the company.

\section{Methodology of research}

\subsection{Sample}

The sample included in this study comprises 44 Portuguese non-listed companies selected among the ranking of the 500 largest Portuguese companies in 2010 (Exame Magazine, 2010) with annual reports available on the Internet. These companies have adopted the SNC for the first time from 2010 onwards. Trusts and holding companies were excluded, due to the specific activity they perform and the specific regulations of these sectors (Table 2 ).

Table 2. Sample

\begin{tabular}{lr}
\hline Number of companies included in the Exame ranking - 2010 & 500 \\
Number of companies without annual reports available in the internet & 449 \\
Trusts and Holding companies & 7 \\
Final sample & 44 \\
\hline
\end{tabular}

\subsection{Dependent variable}

The financial statements of the sample companies for the years 2010-2011 were content analyzed to assess the level of compliance with the disclosure requirements established by NCRF 7 (Plant, Property and Equipment). Following Morais and Fialho (2008) we constructed a list of 27 items of compliance (Appendix 1 ), based on the disclosures required by NCRF 7 . The compliance with the disclosure requirements was assessed (Akhtanruddin, 2005; Gastón et al., 2010; Lopes and Rodrigues, 2007; Tsalavoutas, 2011):

-Assumes " 1 " if the company complies with the disclosure requirement;

-Assumes " 0 " if the company does not comply with the disclosure requirement;

-Assumes "non-applicable" if a certain item of disclosure does not need to be disclosed.

The dependent variable involves the construction of a disclosure score (DS). The DS is the number of disclosures of the company $j$ in each year $i$, calculated in the following way:

$D S j i=\sum_{i=1}^{n j} x i j$

Where:

$n j=$ Number of relevant disclosure items (excluding items not applicable) for the company $j$ $(n j \leq 27)$ :

$x i j=$ Assumes 1 if the item was disclosed, and 0 otherwise. 


\subsection{Independent variables}

Table 3 presents a summary of the independent and control variables for each hypothesis and the measures used for each variable, as well as the expected sign.

Table 3. Definition and predicted signs for independent and control variables

\begin{tabular}{llc}
\hline Variables & Proxies & $\begin{array}{c}\text { Expected } \\
\text { Sign }\end{array}$ \\
\hline $\begin{array}{ll}\text { Independent } \\
\text { Company Size }\end{array}$ & Total assets (million euros) & + \\
& Total Sales (million euros) & + \\
& Number of Employees & + \\
Leverage & Debt to equit ratio ( total debt to equity) & + \\
Foreign Activity & Ratio foreign sales to total sales & + \\
Profitability & Return on equity ration = income before tax to equity & + \\
& Return on assets ratio = income beforre tax to total assets & + \\
Age & Number of years the company has been in operation since inception & + \\
Control & & \\
Industry & Dummy variable = 1 if company belongs to manufacturing, 0 otherwise \\
Type of Auditor & Dummy variable = 1 if auditing firm is a BlG4, 0 otherwise
\end{tabular}

The variable "company size" was assessed using the variables total assets (TA), total sales (TS), and number of employees (NE) (Oliveira et al., 2006; Oliveira et al., 2011a; Branco and Rodrigues, 2008). These size variables were highly correlated. Principal components analysis was applied to generate an index for size. Only one component, explaining 62 per cent (2010) and 61 per cent (2011) of the total variance, was extracted (Eigenvalue $>1$ ). The principal components analysis was validated by the KMO measure of sampling adequacy (2010: $\mathrm{KMO}=0.637 ; 2011: \mathrm{KMO}=0.635)$ and Bartlett's test of sphericity $\left(2010: \chi^{2}=\right.$ 21.879 and a $p$-value $<0.01 ; 2011: \chi^{2}=20.904$ and a $p$-value $\left.<0.01\right)$. The component extracted represents a unique composite index for the $j$ company:

Size $_{2010}=0.746 \times \mathrm{TA}+0.844 \times \mathrm{TS}+0.765 \times \mathrm{NE}$

Size $_{2011}=0,697 \times \mathrm{TA}+0,829 \times \mathrm{TS}+0,809 \times \mathrm{NE}$

The variable "leverage" was measured by the debt-to-equity ratio (Oliveira et al., 2006).

The variable "foreign activity" was measured by the ratio of foreign sales to total sales (Oliveira et al., 2006).

The variable "profitability" was measured by the return on equity (ratio income before tax to equity) and return on assets (ratio income before tax to total assets) (Oliveira et al., 2006; Oliveira et al., 2011a).

The control variables considered were: "industry" and "type of auditor". Several authors confirm that the industry is an indicator that influences, positively, the level of disclosure (Aljifri, 2008; Hackston and Milne, 1996; Lopes and Rodrigues, 2007; Oliveira et al., 2006). However, Tsalavoutas (2011) found a significant negative association between the industry and the degree of compliance with the disclosures required by NCRF 7. Additionally, Gastón et al. (2010) concluded that this variable is not relevant.

Companies audited by one of the Big 4 auditing firms present higher levels of disclosure (Archambault and Archambault, 2003; Oliveira et al., 2006; Tsalavoutas, 2011). Other authors (Lopes and Rodrigues, 2007; Adelopo, 2011) studied this variable and concluded that the level of disclosure is significantly related to the type of auditor and that there is a positive relationship between this variable and voluntary disclosure. However, Morais and Fialho (2008) found no relationship between the type of auditor and the level of disclosure. 
The variable "industry" was measured by a dummy variable that takes the value 1 if the company falls within the manufacturing sector and the value 0 otherwise. The selection of the two types of activity relates to the fact that we expect manufacturing companies to need more investment in PPE and, thus, present higher levels of disclosure (Gastón et al., 2010; Aljifri, 2008).

The variable "type of auditor" was measured by a dummy variable that takes the value 1 if the audit firm is one of the Big 4, taking the value 0, otherwise (Oliveira et al., 2006; Oliveira et al., 2011a).

\subsection{Estimation Model}

The estimation model will test whether the determinants affect the level of compliance with the disclosure requirements proposed by NCRF 7:

$$
\begin{aligned}
& \text { DS }_{j j}=\alpha_{0}+\beta_{1} \text { Company Syze }+\beta_{2} \text { Leverage }_{j}+\beta_{3} \text { Foreign Activity }_{j}+\beta_{4} \text { Profitability }_{j}++\beta_{5} \text { Age }_{j}+\beta_{6} \text { Activity }_{j}+ \\
& \beta_{7} \text { Profitability }{ }_{j}+\beta_{8} \text { Sector of Activity }{ }_{j}+\beta_{9} \text { Type of Auditor }_{j}+\ldots+\mu_{l}
\end{aligned}
$$

\section{Results}

\subsection{Descriptive analysis}

Table 4 shows that, from a total of 27 items of disclosure required by NCRF 7, companies on average comply with 10.16 items in 2010, and with 9.93 items in 2011. The maximum of disclosures found per company, in both years, was 16 items. However, it is interesting to observe that some companies did not have to comply with all disclosure requirements.

Table 4. Descriptive statistics for the sample firms 


\begin{tabular}{lcrrrrr}
\hline & Mensurament & N & Minimum & Maximum & Mean & $\begin{array}{r}\text { Standard } \\
\text { Deviation }\end{array}$ \\
\hline Panel A: 2010 & & & & & & \\
Disclosure score & Sum & 44 & 8.00 & 16.00 & 10.16 & 2.33 \\
Total assets & MEuros & 44 & 9.14 & $2,284.64$ & 365.50 & 484.10 \\
Total sales & MEuros & 44 & 0.00 & $1,401.09$ & 155.22 & 252.46 \\
Number of employees & Sum & 44 & 9.00 & $13,339.00$ & $1,619.32$ & $3,065.01$ \\
Leverage & Ratio & 44 & -8.52 & 5.05 & 0.05 & 2.10 \\
Foreign activity & Ratio & 44 & 0.00 & 0.86 & 0.07 & 0.20 \\
Return on equity & Ratio & 44 & -1.06 & 0.68 & 0.08 & 0.28 \\
Return on assets & Ratio & 44 & 4.00 & 167.00 & 43.91 & 36.04 \\
Age & Sum & 44 & 4.00 & 491.00 & 54.14 & 76.42 \\
& & & & & & \\
Panel B: 2011 & & & & & & \\
Disclosures score & Sum & 44 & 8.00 & 16.00 & 9.93 & 2.06 \\
Total assets & MEuros & 44 & 6.12 & $2,395.38$ & 358.57 & 480.00 \\
Total sales & MEuros & 44 & 0.00 & $1,315.05$ & 145.74 & 236.06 \\
Number of employees & Sum & 44 & 11.00 & $12,468.00$ & $1,442.05$ & $2,746.19$ \\
Leverage & Ratio & 44 & -8.14 & 9.44 & 0.16 & 2.38 \\
Foreign activity & Ratio & 44 & 0.00 & 1.00 & 0.06 & 0.19 \\
Return on equity & Ratio & 44 & -1.53 & 1.25 & 0.04 & 0.37 \\
Return on assets & Ratio & 44 & -0.50 & 0.33 & -0.01 & 0.13 \\
Age & Sum & 44 & 5.00 & 168.00 & 44.91 & 36.04
\end{tabular}

Categorical Variables

Industry

$$
\begin{array}{rrr}
\text { Dummy }=\text { Manufacturing } & 6 & 14 \% \\
\text { Dummy = Others } & 38 & 86 \%
\end{array}
$$

Type of auditor

$$
\begin{array}{ccc}
\text { Dummy }=\text { Big4 } & 15 & 34 \% \\
\text { Dummy }=\text { Others } & 29 & 66 \%
\end{array}
$$

Definition of variables: leverage = debt to equity ratio; foreign activity = ratio of foreign sales to total sales; return on equity = ration of income before tax to equity; return on assests = ratio of income beforre tax to total assets; age = number of years the company has been in operation since inception; industry = 1 if company belongs to manufacturing, 0 otherwise; type of auditor $=1$ if auditing firm is a BIG4, 0 otherwise)

Table 4 also shows that mean values of the independent variables present higher values in 2010 when compared to 2011. This can be a consequence of the first time adoption of the new accounting frame of reference in 2010. However, the leverage presents a higher level in 2011 when compared to 2010. This is a reflection of the lack of liquidity felt by companies, as a consequence of the recent global financial crisis and the sovereign debt crisis in Portugal.

Table 5. Differences in the mean values of dependent and independent variables 


\begin{tabular}{|c|c|c|c|}
\hline & \multicolumn{2}{|c|}{ Mean values } & \multirow{2}{*}{ Z } \\
\hline & 2010 & 2011 & \\
\hline Disclosure score & 10.16 & 9.93 & -0.995 \\
\hline Company size & 403.67 & 370.75 & $-4.376 * *$ \\
\hline Leverage & 0.05 & 0.16 & -0.755 \\
\hline Foreign activity & 0.07 & 0.06 & -0.84 \\
\hline Return on equity & 0.08 & 0.04 & -1.004 \\
\hline Return on assets & 43.91 & -0.01 & -1.389 \\
\hline Age & 54.14 & 44.91 & $-6.633^{* *}$ \\
\hline
\end{tabular}

Differences statistically significant at: * 0.05 , and ${ }^{* *} 0.01$ levels (two-tailed).

Definition of variables: company size = principal components analyisi (total assets, total sales, number of employees); leverage = debt to equity ratio; foreign activity = ratio of foreign sales to total sales; return on equity = ration of income before tax to equity; return on assests = ratio of income beforre tax to total assets; age = number of years the company has been in operation since inception; industry $=1$ if company belongs to manufacturing, 0 otherwise; type of auditor $=1$ if auditing firm is a BIG4, 0 otherwise)

Table 5 presents the results of the non-parametric tests of Wilcoxon to assess the differences in the mean values of the dependent and independent variables between 2010 and 2011 . Findings indicate that those differences were not statistically significant.

\subsection{Regression testing}

Pearson correlations were determined as presented in Table 6. To test for the existence of multicollinearity, we computed variance inflation factors (VIFs). The highest VIF is above 2, suggesting that the problem of multicollinearity is minimal. Table 6 (Panel A) shows that in 2010 there is a statistically significant correlation ( $p$-value $<0.01$ ) between the disclosure score and the age of the company. In 2011, findings indicate a statistically significant correlation between the disclosure score and company size ( $p$ value $<0.05$ ), and between the disclosure score and the age of the company ( $p$-value $<0.01$ ).

Ordinary least squares (OLS) multiple regressions, for each year, were used to test the interrelationship between the various independent and control variables and the disclosure score. To assure the stability of the regression model, the assumptions underlying the regression models were tested for autocorrelation, multicollinearity, heterocedasticity, outliers and influential observations, and the normality of residuals. White's heteroscedasticity test was performed on each model for unequal variances, and heteroscedasticity was corrected by the White matrix. One influential observation was removed from the analysis in both years. The Kolmogorov-Smirnov Lilliefors test suggested that the raw dependent variables and the continuous independent variables did not follow a normal distribution. Therefore, before running the regression models, dependent variables and continuous independent variables were transformed into normal scores using Blom's transformation (Cooke, 1998). The correlation matrix and the regression analysis were performed on the transformed data. 
Table 6. Bivariate relationships for the independent and control variables

\begin{tabular}{|c|c|c|c|c|c|c|c|c|c|}
\hline & $(1)$ & $(2)$ & (3) & (4) & (5) & (6) & (7) & (8) & (9) \\
\hline \multicolumn{10}{|l|}{ Panel A: Year 2010} \\
\hline (1) Disclosure score & 1.000 & & & & & & & & \\
\hline (2) Company size & 0.264 & 1.000 & & & & & & & \\
\hline (3) Leverage & 0.095 & -0.055 & 1.000 & & & & & & \\
\hline (4) Foreign activity & -0.079 & -0.073 & 0.223 & 1.000 & & & & & \\
\hline (5) Return on equity & -0.184 & 0,354 * & 0.050 & 0.069 & 1.000 & & & & \\
\hline (6) Return on assets & -0.193 & 0.120 & 0.169 & 0.119 & $0,576 * *$ & 1.000 & & & \\
\hline (7) Age & $0,521 * *$ & 0.277 & 0.016 & 0.117 & 0.001 & -0.111 & 1.000 & & \\
\hline (8) Industry & -0.006 & -0.124 & -0.040 & 0.085 & 0.185 & 0.265 & 0.221 & 1.000 & \\
\hline (9) Type of auditor & -0.128 & 0.241 & -0.178 & -0.235 & 0.003 & 0.118 & 0.092 & -0.006 & 1.000 \\
\hline
\end{tabular}

Panel B: Year 2011

\begin{tabular}{|c|c|c|c|c|c|c|c|c|c|}
\hline (1) Disclosure score & 1.000 & & & & & & & & \\
\hline (2) Company size & 0,305 * & 1.000 & & & & & & & \\
\hline (3) Leverage & -0.054 & -0.078 & 1.000 & & & & & & \\
\hline (4) Foreign activity & -0.055 & -0.079 & 0.223 & 1.000 & & & & & \\
\hline (5) Return on equity & 0.076 & $0,380 *$ & -0.250 & -0.196 & 1.000 & & & & \\
\hline (6) Return on assets & -0.029 & 0.094 & 0.136 & 0.000 & $0,316 *$ & 1.000 & & & \\
\hline (7) Age & $0,564 * *$ & 0.279 & -0.034 & 0.143 & 0.032 & 0.016 & 1.000 & & \\
\hline (8) Industry & 0.141 & -0.170 & 0.003 & 0.139 & -0.183 & 0.190 & 0.221 & 1.000 & \\
\hline (9) Type of auditor & -0.172 & 0.233 & -0.151 & -0.202 & 0.163 & 0.143 & 0.092 & -0.006 & 1.000 \\
\hline \multicolumn{10}{|c|}{ Significant at: * 0.05 level, and ${ }^{* *} 0.01$ level (two-tailed) } \\
\hline \multicolumn{10}{|c|}{$\begin{array}{l}\text { Definition of variables: company size = principal components analyisi (total assets, total sales, number of employees); } \\
\text { leverage = debt to equity ratio; foreign activity = ratio of foreign sales to total sales; return on equity = ration of income before } \\
\text { tax to equity; return on assests = ratio of income beforre tax to total assets; age = number of years the company has been in } \\
\text { operation since inception; industry = } 1 \text { if company belongs to manufacturing, } 0 \text { otherwise; type of auditor = } 1 \text { if auditing firm } \\
\text { is a BIG4, } 0 \text { otherwise) }\end{array}$} \\
\hline
\end{tabular}

Table 7 shows that the regression models are statistically significant in both years ( $p$-value $<0.01$ ) for the number of disclosures on PPE (2010: $R^{2}$ adjusted $=0.376 ; 2011: R^{2}$ adjusted $\left.=0.433\right)$. The removal of outliers improved the previous $\mathrm{R}^{2}$ adjusted (2010: from 0.31 to 0.376 ; 2011 : from 0.324 to 0.433 ).

The number of disclosures on PPE, in both years, is associated negatively with foreign activity ( $p$ value <0.01), and type of auditor (2010: $p$-value < 0.05; 2011: p-value < 0.01). Hypothesis H3 is not supported. Portuguese unlisted companies that present higher degrees of internationalization do not have incentives to manage stakeholders' perception of their good corporate reputation management skills, through the disclosure of more information on PPE. Perhaps, other kind of information would be more appropriate and selected by managers throughout this process. However, this finding corroborates prior literature (Gastón et al., 2010). Authors found that the effect of IAS/IFRS was less significant in companies with a higher degree of internationalization.

Portuguese unlisted companies not audited by the BIG 4 auditing firms' present higher levels of disclosure on PPE. This finding contradicts previous findings (Archambault \& Archambault, 2003; Oliveira et al., 2006; Tsalavoutas, 2011; Lopes and Rodrigues, 2007; Adelopo, 2011). Agency theory suggests that companies with high agency costs tend to contract higher quality auditing firms - the BIG 4 international auditing firms - to reduce those costs (Jensen and Meckling, 1976). However, the Portuguese unlisted companies have low levels of agency costs. They are mainly family-dominated, with a complex network of ownership, and a substantial number of shares owned by one single shareholder (Mota, 2003).

The number of disclosures on PPE, in both years, is associated positively with the age of the company ( $p$-value $<0.01$ ). Hypothesis H5 is supported. Older companies with higher levels of corporate reputation disclose more information on PPE to manage stakeholders' perception of their reputation.

The number of disclosures on PPE is not associated with company size, leverage, and profitability. Hypotheses $\mathrm{H} 1, \mathrm{H} 2$, and $\mathrm{H} 3$ are not supported. These findings were expected due to the highly concentrated ownership structures of Portuguese unlisted companies, which reduce agency costs. Moreover, the profitability of Portuguese companies has been decreasing since 2007, due to recent global financial crisis effects and the Portuguese sovereign debt crisis. 
Table 7. Results of regression model for number of disclosures

\begin{tabular}{lccc}
\hline Variables & $\begin{array}{c}\text { Expected } \\
\text { sign }\end{array}$ & Disclosure Score 2010 & Disclosure Score 2011 \\
\hline Constant & & 0,161 & 0,137 \\
Company size & + & 0,225 & 0,170 \\
Leverage & $?$ & 0,096 & $-0,031$ \\
Foreign activity & + & $-0,433^{* *}$ & $-0,465^{* *}$ \\
Return on equity & + & $-0,230$ & 0,071 \\
Return on assets & + & 0,035 & 0,000 \\
Age & + & $0,443^{* *}$ & $0,480 * * *$ \\
Sector of activity & & 0,020 & 0,373 \\
Type of auditor & & $-0,467 *$ & $-0,563 * *$
\end{tabular}

$\begin{array}{cll}\text { Model Fit } & & \\ \mathrm{F} & 4,164 * * & 5,010 * * \\ \mathrm{R}^{2} & 0,495 & 0,541 \\ \mathrm{R}^{2} \text { Adjusted } & 0,376 & 0,433 \\ \text { Durbin-Watson } & 1,927 & 2,038\end{array}$

Significance at: ${ }^{*} 0.05$, and ${ }^{* *} 0.01$ levels (two-tailed), respectively; dependent and independent continuous variables were normalised using Blom's transformation. White heteroskedasticity-consistent standard errors, when necessary.

Definition of variables: company size = principal components analyisi (total assets, total sales, number of employees); leverage = debt to equity ratio; foreign activity = ratio of foreign sales to total sales; return on equity = ration of income before tax to equity; return on assests $=$ ratio of income beforre tax to total assets; age $=$ number of years the company has been in operation since inception; industry $=1$ if company belongs to manufacturing, 0 otherwise; type of auditor $=1$ if auditing firm is a BIG4, 0 otherwise)

\section{Conclusions, limitations and future research}

This study intends to analyze the degree of compliance with the disclosure requirements under NCRF 7 for the years 2010 and 2011. Portuguese companies presented very interesting levels of compliance with the disclosure requirements proposed by NCRF 7, basically because most of the companies did not need to comply with all those disclosure requirements.

Our analysis of PPE disclosures by Portuguese unlisted companies reveals that arguments based on the agency theory are not appropriate to understand managers' disclosure policies, and their level of compliance with mandatory disclosure requirements. Findings indicate that older companies with lower degrees of internationalization disclose more information on PPE. Through the disclosure of more information on PPE, managers try to influence the way stakeholders perceive corporate reputation management. This promotes confidence among relevant stakeholders and, consequently, helps guarantee a continuous inflow of resources to the company.

Several limitations should be noted. First, the sample selected is very small. Further research should use a larger sample to confirm the expected results. Second, the present study has only considered two years after the adoption of the new Portuguese accounting frame of reference - the Portuguese Accounting Standardization System (SNC). Further studies should try to assess the effects of the adoption of this new accounting frame of reference on the motivations for complying with the disclosure requirements on PPE, including in that sample some years previous to SNC adoption. 


\section{References}

1. Adelopo, I. (2011). Voluntary disclosure practices amongst listed companies in Nigeria. Advances in Accounting, 27 (2), 338-345.

2. Akhtaruddin, M. (2005). Corporate mandatory disclosure practices in Bangladesh. The International Journal of Accounting, 40 (4), 399-422.

3. Aljifri, K. (2008). Annual report disclosure in a developing country: The case of the UAE. Advances in Accounting, 24 (1), 93-100.

4. Archambault, J.J. \& Archambault, M.E. (2003). A multinational test of determinants of corporate disclosure.The International Journal of Accounting, 38 (2), 173-194.

5. Aharony, J., Barniv, R. \& Falk, H. (2010). The impact of mandatory IFRS adoption on equity valuation of accounting numbers for security investors in the EU. European Accounting Review, 19 (3), 535578.

6. Armstrong, C., Barth, M.E. \& Riedl, E.J. (2010). Market reaction to the adoption of IFRS in Europe. The Accounting Review, 85 (1), 31-61.

7. Birt, J.L., Bilson, C.B., Smith, T. \& Whaley, R.E. (2006). Ownership, competition and financial disclosure, Australian Journal of Management, 31 (2), 235-263.

8. Barth, M.E., Landsman, W.R. \& Lang, M.H. (2008). International accounting standards and accounting quality. Journal of Accounting Research, 46 (3), 467-498.

9. Beuren, I., Heion, N. \& Klann R. (2008). Impact of the IFRS and US-GAAP on economic financial indicators. Managerial Auditing Journal, 23 (7), 632-649.

10. Branco, M.C. \& Rodrigues, L.L. (2008). Social responsibility disclosure: a study of proxies for the public visibility of Portuguese banks. British Accounting Review, 40 (2), 161-81.

11. Callao, S.G., Jarne, J. \& Laínez, J. (2007.) Adoption of IFRS in Spain: effect on the comparability and relevance of financial reporting. Journal of International Accounting, Auditing and Taxation, 16 (2), 148-178.

12. Callao, S.G., García, C.F., Jarne, J.I. \& Gadea, J.A. (2010). IFRS adoption in Spain and the United Kingdom: effects on accounting numbers and relevance. Advances in Accounting, incorporating Advances in International Accounting, 26 (2), 304-313.

13. Christensen, L.T. (2002). Corporate communication: the challenge of transparency. Corporate Communications: an International Journal, 7 (3), 162-168.

14. Cooke, T.E. (1998). Regression analysis in accounting disclosures studies. Accounting \& Business Research, 28 (3), 209-24.

15. Cooke, T. (1989). Voluntary corporate disclosure by Swedish companies. Journal of International Financial Management and Accounting, 1 (2), 171-95.

16. Cunha, J.V.A. \& Ribeiro, M.S. (2008). Divulgação voluntária de informações de natureza social: um estudo nas empresas brasileiras. Revista de Administração - eletrônica- SP, 1 (6), 1-23.

17. Daske, H., Hail, L., Luez, C. \& Verdi, R. (2008). Mandatory IFRS reporting around the world: early evidence on the economic consequences. Journal of Accounting Research, 46 (5), 1085-1141.

18. Deephouse, D.L., (1996). Does isomorphism legitimate, Academy of Management Journal, 39 (4), 1024-1039.

19. Depoers, F. (2000). A cost-benefit study of voluntary disclosure: some empirical evidence from French listed companies. The European Accounting Review, 9 (2), 245-63.

20. Devalle, A., Onali, E. \& Magarini, R. (2010). Assessing the value relevance of accounting data after the introduction of IFRS in Europe. Journal of International Financial Management and Accounting, 21 (2), 85-119.

21. Diamond, D.W. (1989). Reputation acquisition in debt markets. Journal of Political Economy, 97 (4), 828-61.

22. DiMaggio, P.G. \& Powell, W.W., (1983). The iron cage revisited: institutional isomorphism and collective rationality in organizational fields. American Sociological Review, 48, 147-160.

23. Ding,Y., Hope, O., Jeanjean, T. \& Stolowy, H. (2007). Differences between domestic accounting standards and IAS: measurement, determinants and implications. Journal of Accounting and Public Policy, 26 (1), 1-38. 
24. Fernandéz-Alles, M.L. \& Valle-Cabrera, R. (2006). Reconciling institutional theory with organizational theories: how neo-institutionalism resolves five paradoxes, Journal of Organizational Change Management, 19 (4), 503-517.

25. Freeman, R.E. (1984). Strategic management: a stakeholder approach, Marshall, MA Pitman.

26. Fifield, S., Finningham, G., Fox, A., Power, D., \& Veneziani, M. (2011). A cross-country analysis of IFRS reconciliation statements. Journal of Applied Accounting Research, 12 (1), 26-42.

27. Gassen, J. \& Sellhorn, T. (2006). Applying IFRS in Germany: determinants and consequences: SSRN working paper.

28. Gastón, S.C., García, C.F., Jarne, J.I.J. \& Gadea, J.A.L. (2010). IFRS adoption in Spain and the United Kingdom: Effects on accounting numbers and relevance. Advances in Accounting, 26 (2), 304-313.

29. Goncharov, I. \& Zimmermann, J. (2006). Do accounting standards influence the level of earnings management? Evidence from Germany: SSRN working paper.

30. Hackston, D. \& Milne, M.J. (1996). Some determinants of social and environmental disclosures in New Zealand companies. Accounting, Auditing \& Accountability Journal, 9, 77-108.

31. Haller, A., Ernstberger, J., \& Froschhammer, M. (2009). Implications of the mandatory transition from national GAAP to IFRS: empirical evidence from Germany. Advances in Accounting, incorporating Advances in International Accounting, 25 (2), 226-236.

32. Hibbitt, C.J., (2004). External Environmental Disclosure and Reporting by Large European Companies - An Economic, Social and Political Analysis of Managerial Behaviour. VrijeUniversiteit Amsterdam, Netherlands.

33. Iatridis, G. \& Rouvolis, S. (2010). The post-adoption effects of the implementation of International Financial Reporting Standards in Greece. Journal of International Accounting, Auditing and Taxation, 19 (1), 55-65.

34. latridis, G.E. (2012). Voluntary IFRS disclosures: evidence from the transition from UK GAAP to IFRSs. Managerial Auditing Journal, 27 (6), 573-597.

35. Jeanjean, T. \& Stolowy, H. (2008). Do accounting standards matter? An exploratory analysis of earnings management before and after IFRS adoption. Journal of Accounting and Public Policy, 27 (6), 480494.

36. Jensen, M.C. \& Meckling, W.H. (1976). Theory of the firm: managerial behavior, agency costs and ownership structure. Journal of Financial Economics, 3 (4), 305-360.

37. Lang, M. \& Lundholm, R. (1992). An empirical assessment of voluntary disclosure theory. Working Papers - Stanford Graduate School of Business, Research Paper N.ㅇ 1188, 1-54.

38. Lantto, A. \& Sahlström, P. (2009). Impact of International Financial Reporting Standard adoption on key financial ratios. Accounting \& Finance, 49 (2), 341-361

39. Liu, C. (2011). IFRS and US-GAAP comparability before release No. 33-8879: some evidence from US-listed Chinese companies. International Journal of Accounting and Information Management, 19 (1), 2433.

40. Lopes, P.T. \& Rodrigues, L.L. (2007). Accounting for financial instruments: An analysis of the determinants of disclosure in the Portuguese stock exchange. The International Journal of Accounting, 42 (1), 25-56.

41. Morais, A.I. \& Curto, J. (2008). Accounting quality and the adoption of IASB standards: Portuguese evidence. Revista Contabilidade e Finanças, 19 (48), 103-111.

42. Morais, A. I. \& Fialho, A. (2008). Do harmonised accounting standards lead to harmonised accounting practices? An empirical study of IAS 39 measurement requirements in some European Union countries. Australian Accounting Review, 18 (3), 224-236.

43. Morris, R.D., (1987). Signalling, agency theory and accounting policy choice. Accounting and Business Research, 18 (69), 47-56.

44. Mota, N. (2003). Ownership structure and firm performance: the Portuguese evidence. Master of Management Dissertation. Oporto Faculty of Economics. Portugal.

45. Oliveira, L., Rodrigues, L. L. \& Craig, R. (2006). Firm-specific determinants of intangibles reporting: evidence from the Portuguese stock market. Journal of Human Resource Costing \& Accounting, 10 (1), 1133. 
46. Oliveira, J., Rodrigues, L.L. \& Craig, R. (2011a). Risk-related disclosures by non-finance companies: Portuguese practices and disclosure characteristics. Managerial Auditing Journal, 26 (9), 817-839.

47. Oliveira, J., Rodrigues, L.L. \& Craig, R. (2011b). Voluntary risk reporting to enhance institutional and organizational legitimacy: evidence from Portuguese banks. Journal of Financial Regulation and Compliance, 19 (3), 271-288.

48. Olivier, C., (1991). Strategic responses to institutional processes. Academy of Management Review, 16 (1), 145-179.

49. Raffournier, B. (1995). The determinants of voluntary financial disclosure by Swiss listed companies. European Accounting Review, 4 (2), pp. 261-80.

50. Ross, S., (1977). The determination of financial structure: the incentive-signalling approach, Bell Journal of Economics, 8 (1), 23-40.

51. Salotti, B.M. \& Yamamoto, M.M. (2008). Divulgação voluntária da demonstração dos fluxos de caixa no mercado de capitais brasileiro. Revista Contabilidade \& Finanças, USP,19 (48), pp. 37-49.

52. Shocker, E.D. \& Sethi, S.P. (1974). An approach to incorporating social preferences in developing corporate action strategies. The Unstable Groung: corporate social policy in a dynamic society, Melville Publishing Company, Los Angeles.

53. Tendeloo, B.V. \& Vanstraelen, A. (2005). Earnings management under German GAAP versus IFRS. European Accounting Review, 14 (1), 155-180.

54. Tsalavoutas, I. \& Evans, L. (2007). Comparing International Financial Reporting Standards (IFRSs) and Greek GAAP: Financial Statements Effects, Workshop on Accounting in Europe, France: working paper

55. Trombetta, M., Wagenhofer, A. \& Wysocki, P. (2012). The Usefulness of Academic Research in Understanding the Effects of Accounting Standards. Accounting in Europe, 9 (2), 127-146.

56. Tsalavoutas, I. (2011). Transition to IFRS and compliance with mandatory disclosure requirements: What is the signal? Advances in Accounting, 27 (2), 390-405.

57. Watts, R.L. \& Zimmerman, J.L. (1986). Positive Accounting Theory. Englewood-Cliffs. 


\section{Appendix 1}

\begin{tabular}{|c|c|c|}
\hline & Items & Companies \\
\hline \multicolumn{2}{|r|}{ The entity has Property, Plant \& Equipment assets? } & $(1 / 0 / N A)$ \\
\hline \multicolumn{3}{|c|}{ i. If yes, discloses: } \\
\hline & The measurement bases used for determining the gross book value & $(1 / 0 / N A)$ \\
\hline & The depreciation methods & $(1 / 0 / N A)$ \\
\hline c) & The useful lives or the depreciation rates & $(1 / 0 / N A)$ \\
\hline & $\begin{array}{l}\text { The gross book value and the accumulated depreciation (aggregated with accumulated } \\
\text { pairment losses) at the beginning and end of the period }\end{array}$ & $(1 / 0 / N A)$ \\
\hline e) & A reconciliation of the book value at the beginning and end of the period & $(1 / 0 / N A)$ \\
\hline & $\begin{array}{l}\text { Depreciation, whether recognized in the income statement or as part of the cost of other assets, } \\
\text { ing a period }\end{array}$ & $(1 / 0 / N A)$ \\
\hline & Accumulated depreciation at the end of the period & $(1 / 0 / N A)$ \\
\hline & $\begin{array}{l}\text { The existence and amounts of ownership restrictions and tangible fixed assets that are pledged } \\
\text { security for liabilities }\end{array}$ & $(1 / 0 / N A)$ \\
\hline i) & The amount of expenditures recognized in the book value of an FTA item during its construction & $(1 / 0 / N A)$ \\
\hline j) & The amount of contractual commitments for the acquisition of FTA & $(1 / 0 / N A)$ \\
\hline & $\begin{array}{l}\text { The amount of compensation from third parties for items of the FTA that were impaired, lost or } \\
\text { en up that is included in the income statement }\end{array}$ & $(1 / 0$ / NA $)$ \\
\hline
\end{tabular}

i. The company adopts the revaluation model and by class of intangible assets discloses:

a) The effective date of the revaluation

b) If was involved an independent appraiser

c) Indication of fair value determination:

1. Directly by reference to observable prices in an active market

2. Recent market transactions on a non-relationship basis between the parties

3. The book value of the revaluation surplus, indicating the change for the period and any restrictions on the distribution of the balance to shareholders

4. Methods and significant assumptions applied in estimating assets fair value

i. Regarding impairment, for each class of assets:

a) The amount of impairment losses recognized in the period

b) The amount of reversals of impairment losses recognized in the period

c) The amount of impairment losses on revaluated assets recognized in equity in the period

d) The amount of reversals of impairment losses on revaluated assets recognized in equity in the period

J. As for changes in accounting estimates:

a) The amount of a change in an accounting estimate

b) If the amount of the estimate is impracticable, disclose that fact 